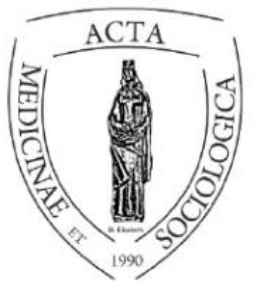

Acta Medicinae et Sociologica (2021)

Vol. 12. No. 32. (50-66)

UNIVERSITY OF

DEBRECEN

doi:

FACULTY OF

HEALTH

https://doi.org/10.19055/ams.2021.05/31/3 NYÍREGYHÁZA

\title{
Migránsok gyermekeinek szocializációja
}

\section{Dajnoki Krisztina $^{1}$, Balázs-Földi Emese ${ }^{2}$, Móré Marianna ${ }^{3}$}

${ }^{1}$ habilitált egyetemi docens, intézetigazgató, Debreceni Egyetem Gazdaságtudományi Kar, Vezetés- és Szervezéstudományi Intézet, 4032 Debrecen, Böszörményi út 138

${ }^{2}$ adjunktus, Debreceni Egyetem Gyermeknevelési és Gyógypedagógiai Kar, Szociálpedagógia Tanszék 4220 Hajdúböszörmény, Désány István u. 1-9

${ }^{3}$ habilitált egyetemi docens, tanszékvezető, dékán, Debreceni Egyetem Egészségügyi Kar, Gerontológiai Tanszék, 4400 Nyíregyháza, Sóstói út 2-4.

\begin{tabular}{|c|c|}
\hline INFO & ABSTRACT \\
\hline @econ.unideb.hu & \multirow[b]{2}{*}{$\begin{array}{l}\text { Tasks related to the inclusion of migrant children pose } \\
\text { significant challenges for teachers. Our study's focus is on the } \\
\text { research question, what factors play a role in the successful } \\
\text { integration process of migrant children? We aim to present } \\
\text { integration challenges, statistical data related to the topic, and } \\
\text { provide a comprehensive overview of the factors that help } \\
\text { students' school integration. We can state that diversity } \\
\text { promotes synergy in the community and positively impacts } \\
\text { effectiveness. At the same time, the school is less effective in } \\
\text { solving social problems. Problem management adjusted to } \\
\text { the school's operation can also contribute to the } \\
\text { reorganization of pedagogical practice and, in the long run, } \\
\text { to social effectiveness. We consider a new type of service } \\
\text { system for school social work to complement the pedagogical } \\
\text { process. In our opinion, the content elements of training } \\
\text { should be extended to describe the helping methods in the } \\
\text { inclusion of migrant children. }\end{array}$} \\
\hline $\begin{array}{l}\text { Keywords } \\
\text { school integration, migrant } \\
\text { children, sensitization, } \\
\text { mentoring }\end{array}$ & \\
\hline $\begin{array}{l}\text { Kulcsszavak } \\
\text { iskolai beilleszkedés, } \\
\text { migráns gyerekek, } \\
\text { érzékenyítés, mentorálás }\end{array}$ & $\begin{array}{l}\text { A migráns gyerekek befogadásával kapcsolatos feladatok } \\
\text { jelenős kihívások elé állítják a pedagógusokat. } \\
\text { Tanulmányunk fókuszában az a kutatási kérdés áll, milyen } \\
\text { tényezők játszanak szerepet a migráns gyerekek sikeres } \\
\text { beillesztési folyamatában? Célunk ismertetni az integrációs } \\
\text { kihívásokat, a kapcsolódó statisztikai adatokat és átfogó } \\
\text { képet adni a tanulók iskolai beilleszkedését segítő }\end{array}$ \\
\hline
\end{tabular}


tényezőkről. Megállapítható, hogy a sokszínűség elősegíti a szinergiát a közösségben, pozitívan hat az eredményességre, ugyanakkor az iskola a társadalmi problémák megoldásában kevésbé hatékony. Az iskola működéséhez igazított problémakezelés a pedagógiai gyakorlat átrendezéséhez, hosszabb távon pedig a társadalmi eredményességhez is hozzájárulhat. A pedagógiai folyamat kiegészítéseként tekintünk az iskolai szociális munka új típusú szolgáltatás rendszerére. Véleményünk szerint képzés tartalmi elemeit érdemes lenne kiterjeszteni a migráns gyerekek befogadását segítő módszerek ismertetésére.

\section{Bevezetés}

A fejlett országokban a gazdasági hatékonyságot és eredményességet akadályozó egyik tényező a munkaerőhiány. Ennek egyik lehetséges megoldása a munkaerő bevándorlókkal, migránsokkal való pótlása. Hazánkban a rendelkezésre álló munkaerő számában mutatkozó deficit szintén problémaként jelentkezik, ugyanakkor a gazdaság fejlődésével egyenes arányban a közeljövőben még komolyabb nehézséget fog okozni. Magyarország sajátos történelmi múltja miatt a határon túli magyarok sikeresen pótolhatják, illetve hosszú távon kielégíthetik a hazai munkaerőpiaci igényeket. Mindezek mellett azonban más országokból érkező bevándorlók, munkavállalók is megjelenhetnek hazánk társadalmi-gazdasági életében. A multinacionális vállalatok alkalmazottainak egy része akár az anyaország állampolgáraiból (jellemzően a menedzsment tagjai), akár más, az Európai Unió országain kívül eső államból is származhatnak, de más Európán kívüli országból érkező bevándorlók (kínai, koreai, vietnami, ukrán, török stb.) is részesei lehetnek a hazai gazdasági életnek. A bevándorlók feltételezhetően nem egyedül, hanem családjukkal érkeznek Magyarországra. Ennek következményeként a bevándorló családok gyermekei megjelennek a hazai köznevelési intézményekben is, amely kihívás elé állítja a területen dolgozó szakembereket. Ezekre a gyerekekre a hazájuktól, kultúrájuktól, családi és baráti kapcsolataiktól való elszakadás miatt, „vulnerable”, azaz sérülékeny gyerekekként kell gondolnunk, akikre kiemelt figyelmet kell fordítani annak érdekében, hogy hosszútávon sikeresen megvalósulhasson a társadalomba és gazdaságba való beilleszkedésük, integrációjuk. 


\section{Bevándorlás}

Az Európai Bizottság 2010-ben fogadta el a Zaragozai Nyilatkozatot, mely a bevándorlással kapcsolatosan az integráció négy területét nevezi meg, így: a foglalkoztatás, az oktatás, a szociális helyzet és az aktív állampolgárság (Gödri 2017).

Az Európai Bizottság (2011) szakpolitikai dokumentumai intézkedésként és fejlesztési célként az alábbi területeket fogalmazták meg: munkaerőpiac, oktatás, politikai-társadalmi aktivitás, nyelvtudás, valamint a kulturális autonómia, az interkulturális kapcsolatok. Az európai integrációs kihívásokkal foglalkozó dokumentum hangsúlyozza a migránsok jelenlétének hatására kialakuló társadalmi és gazdasági előnyöket, ugyanakkor az integrációt kétirányú folyamatként írja le, mely kölcsönös alkalmazkodást kíván a bevándorlóktól és a fogadó társadalomtól is (Gödri 2017).

A harmadik országból érkező migránsok sikeres integrációjához az alábbi kihívásokat fogalmazza meg:

- migránsok (különösen a nők) alacsony foglalkoztatottsága;

- növekvő munkanélküliség és túlképzettség magas szintje;

- társadalmi kirekesztődés fokozódó kockázata;

- iskolai eredmények közötti különbség;

- a bevándorlók beilleszkedésének hiányával kapcsolatban a közvélemény által megfogalmazott aggodalmak.

A társadalmi integrációt, vagyis azt a folyamatot, amelynek során a bevándorlók átveszik-e a befogadó ország nyelvét, kultúráját vagy megtartják etnikai különbségüket Heckmann (2001) alapján számos tényező befolyásolja. Függ többek között a társadalomban uralkodó elöítéletektől, a kultúrák távolságától, a befogadási politikától is.

A népvándorlás, a társadalomban zajló változások hatással vannak a családstruktúrára, a közösségszerveződésre, a kultúrára és az oktatási rendszerekre, ami pedagógiai válaszokat igényel, vagyis a változásokra a pedagógiai gyakorlatnak is reagálnia kell. Ugyanakkor meg kell említeni, hogy a migráns generációk beilleszkedési problémáinak kezelésére a mai napig nem született megoldás (Meleg 2015). A szegregáció-integráció témaköre az oktatásüggyel foglalkozó szakemberek mellett a közvéleményt is erösen foglalkoztatja, ugyanakkor a tájékoztatás és tájékozottság ezen a téren messze nem kielégítő (Fejes 2013).

Hazánkban a Központi Statisztikai Hivatal makro- és mikrocenzusának részét képezik a bevándorlással kapcsolatos adatgyüjtések. A Központi 
Statisztikai Hivatal adatfelvételei során a bevándorlók öt kategóriáját alakították ki (KSH 2018):

- az ország területén született honosítással magyar állampolgárságot szerzettek csoportja,

- a hazánkban született külföldi állampolgárok,

- a külföldön született magyar állampolgárok,

- a külföldön született, de honosítással magyar állampolgárságot szerzettek,

- valamint a külföldön született külföldi állampolgárok csoportja.

A KSH kategorizálása alátámasztja azoknak a kutatásoknak a megállapítását, amelyek szerint a hazánkba érkező bevándorlók nagyobb hányada határon túli magyar, kisebb részük EU-n kívülröl érkezik (Örkény - Székelyi 2010). A 2011-es makrocenzus és a 2016-os mikrocenzus eredményei szerint a Magyarországon élő külföldi állampolgárok aránya jelentősen nem változik, 1,4\% körül mozog. Ez azt jelenti, hogy 2011-ben 137395 ezer, a 2016-ban 136887 ezer fö élt hazánkban külföldi állampolgárként (KSH 2018). A honosítással magyar állampolgárságot szerzők népességen belüli aránya 2016os adatgyüjtés alapján 1,9\%-ot tesz ki (KSH 2018). Származási országuk alapján a külföldi állampolgárok közel 90\%-a Európából érkezik, első helyen Románia (15\%), második helyen Németország (14\%), harmadik helyen Szlovákia (11\%) áll (Kincses 2015). A többiek Európán kívüli országokból származnak, lényegében nincs olyan kontinens, amelynek lakói ne képviseltetnék magukat, közülük is legnagyobb arányban (9\%) a Kínából érkezők vannak (KSH 2018).

A hazánkban élő külföldiek 93\%-a nem Magyarországon született, míg 7\%uk már az országban jött világra (KSH 2018). Ez utóbbi csoport a külföldön született külföldiek gyermekei. A külföldi állampolgárok életkori megoszlásuk alapján a legfiatalabb korosztálynak tekinthetők, 51\%-uk 14 év alatti, 9\%-uk 15-19 év közötti. Szintén magas a fiatal korcsoportba tartozók aránya a Magyarországon született, honosítottak körében, 24\%-uk 14 év alatti, 9\%-uk 15 és 19 év közötti.

Lakóhelyük szempontjából a bevándorlókra jellemző, hogy legnagyobb arányban Közép-Magyarországon, leginkább Budapesten és környékén élnek, kevésbé jelennek meg vidéken, illetve a kisebb településeken.

A migrációs hátterű köznevelésben tanulókról kevés információ áll rendelkezésünkre, a köznevelési statisztikák adatai elsősorban a köznevelési intézményekben tanulók létszámáról és nemzeti hovatartozásáról adnak számot. Papp (2017) tanulmánya alapján a külföldi, illetve bevándorló hátterü 
tanulók számának megállapítása nehézségekbe ütközik, mivel a rendelkezésre álló adatbázisok kategóriarendszere eltérő (pl. migráns tanulók, külföldi állampolgárság, születési ország, nem Magyarországon született, nem magyar anyanyelvü, bevándorló hátterü).

Az Oktatási Hivatal (2016) adatai alapján az általános iskolai telephelyek 49\%-ában, a gimnáziumok 78-80 százalékában lehet találni legalább egy olyan tanulót, aki nem Magyarországon született. Nem magyar anyanyelvü tanulókkal az általános iskolák 17, míg a gimnáziumok 20-25 százalékában lehet találkozni.

$\mathrm{Az}$ 1. ábra adatai alapján megállapítható, hogy a magyar köznevelési rendszerben a legnagyobb arányban az egyéb külföldi tanulók találhatók, ettől jelentősen lemaradva román, szlovák, illetve ukrán származású diákok képviseltetik magukat nagyobb mértékben (Köznevelési Statisztikai Évkönyv 2018/19).

1. ábra: a köznevelésben tanuló bevándorló diákok megoszlása származásuk alapján 2018/19

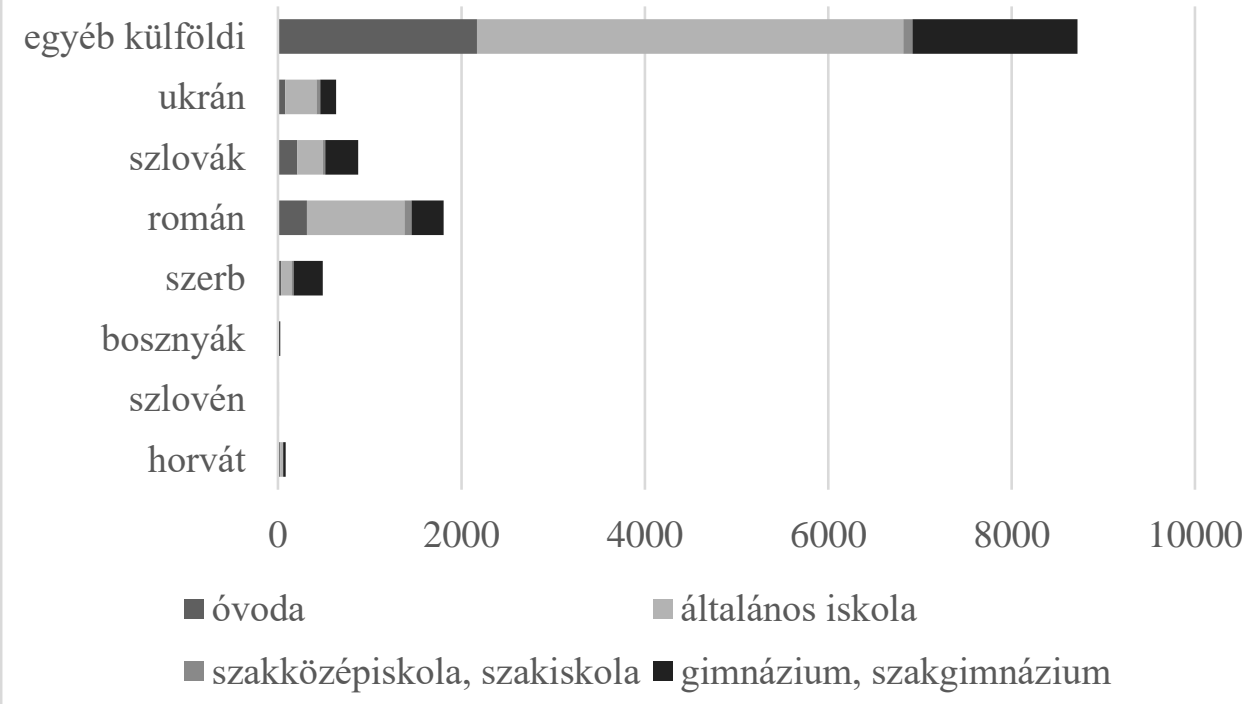

Forrás: Köznevelési Statisztikai Évkönyv 2018/19:37-39 alapján saját szerkesztés

\section{Az iskolai beilleszkedést befolyásoló tényezők}


Kutatási eredmények alapján a tanulók iskolai beilleszkedését a következő tényezők határozzák meg (Feischmidt és Nyíri, 2006; Illés és mtsai 2009; Zatykó, Schumann és Balogi, 2013):

a) a családok szociális helyzete, szocioökonómiai státusza,

b) a családok tanuláshoz való viszonyulása,

c) kulturális identitáshoz való kötődés erőssége,

d) a nyelvtudás,

e) a gyermekek életkora,

f) a család és a diák bevándorlás következményeként jelentkező mentális állapota

g) az iskola és a pedagógusok felkészültsége,

h) szociális segítők, mentorok támogató jelenléte.

Illés - Medgyesi és munkatársai (2009) szerint, bár mindegyik kutató a saját területét jelölte meg a legmeghatározóbb tényezőnek, ezek a tényezők hatnak egymásra, és együttesen határozzák meg a gyerekek iskolai sikerességét. A beilleszkedési tényezőket érvényesnek fogadjuk el, belső tartalmukat következőképpen határozzuk meg:

a) A bevándorló családok szociális helyzete, szocioökonómiai státusza

Habár a statisztikai adatgyüjtésekből nem derül ki, hogy az itt élő bevándorlók milyen arányban rendelkeznek családdal, illetve gyerek(ek)kel, mégis feltételezzük, hogy a migránsok általános szocioökonómiai sajátosságai érvényesek a családdal, gyermekekkel rendelkezőkre is.

A tanulók családi és szociokulturális hátterének ismerete azért is lényeges, mivel a társadalmi integráció sikerességében a gyermeket körülvevő szocializációs színterek mindegyike fontos szerepet játszik. A családi háttér jellemzői, a pénzügyi tőke, a szülök emberi tőkéje, a gyermekekre fordított időinvesztáció mellett a másodlagos szocializációban legfontosabb szerepet játszó iskola hozzáadott értéke szintén meghatározó (Pusztai 2009; R. Fedor 2015; Engler, 2017; R. Fedor és Pálosi 2018). Bronfenbrennen (1979) ökológiai-modelljében rámutat, hogy a gyermekek nevelése során szükséges a holisztikus szemléletmód, mivel a diákok tanulási teljesítményére, fejlődésére hatást gyakorol szükebb-tágabb környezete, így például a család, a társadalomban érvényes kultúra, de a gazdasági környezet is (2. ábra).

A Központi Statisztikai Hivatal adataiból következtethetünk a migráns gyerekek származására, családi hátterére, szocioökonómiai sajátosságaira. (KSH 2018). A rendelkezésre álló adatokból és elemzésekből azokat emeljük ki, amelyek a bevándorló gyermekek társadalmi beilleszkedése szempontjából 
lényegesek lehetnek. A hazai statisztikai adatok elemzése során általánosságban megállapítható, hogy a bevándorlók demográfiai jellemzőik tekintetében eltérő sajátosságokkal rendelkeznek a hazai lakossághoz képest. Egyrészt fiatalabbak, másrészt mind iskolai végzettségük, mind gazdasági aktivitásuk magasabb. Ugyanakkor az is megállapításra kerül, hogy a bevándorlók csoportja nagyon heterogén, és különbségek fedezhetők fel az egyes csoportok jellemzöi között (Örkény és Székelyi 2010; Kováts 2013; Gödri 2008, 2017).

2. ábra: Bronfenbrenner ökológiai modellje

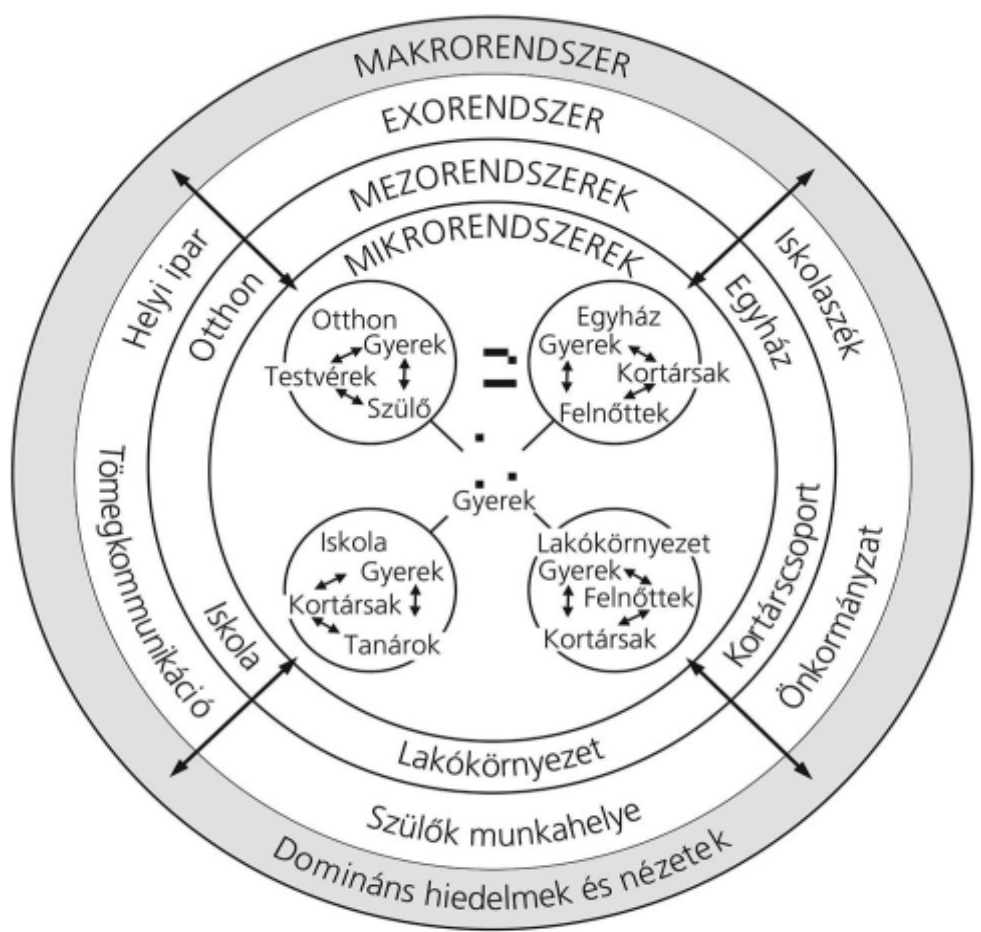

Forrás: Bronfenbrenner, 1979

Fónai és Pénzes (2009) Észak-alföldi Régióban végzett vizsgálatai alapján a bevándorló külföldiek mintegy 70\%-ának volt ismert az iskolai végzettsége, ebböl $16 \%$-uk rendelkezett felsőfokú végzettséggel és minden harmadik személy középfokú végzettséggel. Ennek hátterében részben a fiatal korstruktúra, illetve a gyermekkorúak magas aránya is állhat.

A KSH (2018) eredményei szerint a bevándorlók iskolai végzettsége magasabb a hazai népességhez képest, tehát magasabb körükben a felsőfokú végzettséggel rendelkezők aránya. Azonban eltérések vannak az egyes csoportok között. Az iskolázottság kapcsán fontosnak tartjuk megjegyezni, 
hogy sok külföldről érkező migráns eleve elsősorban felsőfokú tanulmányok végzése céljából tartózkodik Magyarországon.

A témakörben végzett kutatások eltérő eredményekröl adnak számot az iskolai végzettség és a munkaerö-piaci helyzet összefüggésében. Míg egyes kutatási eredmények (Gödri és Tóth 2005; Gödri 2008, 2017; Juhász, Makara P. és Makara E. 2011) szerint az iskolai végzettséghez képest rosszabb munkaerő-piaci pozícióba kerülnek a migránsok, addig más vizsgálatok eredményei szerint sikerül iskolai végzettségüket érvényesíteni a munkaeröpiacon (Örkény és Székelyi 2010).

Gazdasági aktivitásuk a hazai népességhez képest kimondottan jónak mondható, mégis többségük a magasabb iskolai végzettségük ellenére alacsonyabb végzettséget igénylő munkaköröket töltenek be, míg a magyar nyelvet nem beszélők körében (így például a kínaiak, koreaiak) esetében magasabb az önfoglalkoztatók, vállalkozók aránya (Gödri 2017). A nemek gazdasági aktivitása tekintetében különbségek fedezhetők fel, a nők foglalkoztatottsági rátája alacsonyabb a férfiakéhoz képest. Származás alapján azonban további eltérések mutatkoznak, a kínai nők körében magasabb, míg a szíriai nök körében alacsonyabb a foglalkoztatottság (Melegh, Kovács és Gödri 2010; Gödri 2017), tehát a származási ország kultúrája a bevándorlást követően is hatást gyakorol a munkaerő-piaci státuszra, illetve ez a nők elszigetelődésének, magányosságának problémáját is felveti.

A fenti elemzések alapján megállapítható, hogy a hazánkba érkező migránsok több szempontból is nagyon heterogén csoportot alkotnak. Legnagyobb hányaduk határainkon kívüli, magyar származású bevándorló, kisebb arányban Európán kívüli országból érkezik. Mindez markáns különbséget jelent a két bevándorló csoport integrálódásának kérdésében. Míg az előbbi csoportnál nyelvi korlát nem lévén, a beilleszkedés viszonylag rövid idő alatt, zökkenőmentesen, addig az utóbbi csoport esetében hosszabb időt igényelve, komplexebb támogatás és nagyobb odafigyelés mellett valósulhat meg.

b) A családok tanuláshoz való viszonyulása

A migráns tanulók integrálódásának alapvető nehézségei közé tartozik, hogy a család tagjaként átélik azt, hogy a szülők hozott tudásbeli értékei nem azonosak a befogadó országban azzal, ahogyan otthon értékelték, emellett az iskolai teljesítményt nagyban befolyásolja a család, a migráns közösség tanulással és tudással kapcsolatos attitüdje. 
A pedagógusoknak eltérő tapasztalataik van a különböző országokból érkező migráns gyerekekkel kapcsolatosan (Zatykó, Schumann és Balogi, 2013). A határon túli magyar diákok köznevelési intézményekben való megjelenése semmiféle problémát nem jelent, míg egyéb harmadik országbeli (elsősorban távol-keleti) gyerekekkel kapcsolatosan kimondottan pozitív tapasztalatokat fogalmaztak meg tanulási motiváció, a kitartás, a figyelem és alkalmazkodni akarás szempontjából.

c). A kulturális identitáshoz való kötödés erössége

A beilleszkedés egyik faktora a gyermekek, és a családok rugalmassága. A magyar anyanyelvü bevándorló családok gyermekei esetében a köznevelés rendszerébe való beilleszkedés kevésbé problematikus, mint a nem magyar anyanyelvü migráns gyerekek esetében. Azoknak a migráns gyerekeknek a beilleszkedése a legnehezebb, akik a magyar kultúrától nagyon különböző kultúrából és nyelvterületről érkeztek (Jakab 2011). Pásztor (2006:29) kumulatív iskolázottság alapján végzett vizsgálati eredményei azt mutatták, hogy a „kisebbségi fiatalok nem az anyaországhoz, de nem is egymáshoz „,igazodnak”, hanem ahhoz a többségi társadalomhoz próbálnak felzárkózni, ahol élniük kell." Feischmidt és Nyíri (2006) kutatásukban kínai és afgán migráns családok és az iskola kapcsolatát vizsgálják. A két csoport között a kulturális beállítottság alapján jelentős különbségeket fedeztek fel a kutatók. Az eredmények alapján a kínai családok a kulturális identitás megőrzése helyett inkább a társadalmi mobilitás megvalósulását helyezik előtérbe, ezért nagyfokú elkötelezettséget mutatnak a tanulás irányába, és a társadalmi felemelkedés eszközeként tekintenek rá. Az afgánok esetében gyengébb a tanulási motiváció, mivel náluk a kulturális identitás megtartása fontosabbnak mutatkozik.

\section{d) A nyelvtudás}

Barna, Nguyen Luu és Várhalmi (2012), Melegh, Kovács és Gödri (2010) valamint Zatykó, Schumann és Balogi (2013) szerint a nyelvtudás hiánya meghatározza az iskola és a családok közötti kapcsolattartást is. Németh (2009) vizsgálata szerint a nemzetközi trendekhez hasonlóan Magyarországon is problémaként jelenik meg, hogy a tanulók nyelvi kompetenciahiányából fakadó problémáit a pedagógusok képességhiányként, tanulási nehézségként azonosítják, valamint, hogy a tanárok és a szülők közötti kapcsolattartás ritka és rendszertelen. Ez további akadályként jelentkezik a társadalmi beilleszkedés sikerességében. Javaslatuk szerint az iskoláknak lehetőséget kellene biztosítaniuk a magyar nyelv elsajátítására. 


\section{e) A gyermekek életkora}

A változásokhoz való alkalmazkodás során a személyiségnek rugalmassággal kell rendelkeznie- ahhoz, hogy az egyén rövid időn belül, zökkenőmentesen beilleszkedhessen egy számára ismeretlen társadalmi kultúrába. Feischmidt és Nyíri (2006) kutatási eredményei szerint a beilleszkedés sikerességét a gyermek életkora is meghatározza, minél magasabb életkorban kerülnek Magyarországra és a köznevelés rendszerébe a diákok, annál nehezebb számukra ez a folyamat.

\section{f). A család és a diák rezilienciája}

Kevésbé jelenik meg a migráns gyerekekkel kapcsolatosan a migráció lelki oldalára fókuszáló kérdéskör, pedig a társadalmi beilleszkedést befolyásolja a bevándorlással járó sajátos pszichés állapot is. A migráns gyerekek esetében a bizonytalanság, a változások, az otthonelhagyás, a menekülés következtében kialakult zilált lelki állapot, traumák is hozzáadódnak. Habár a gyermek, mint a családi rendszer része, nem rendelkezik döntési lehetőséggel a kivándorlást illetően, de annak következményeit (pl. helyvesztés, a barátok, illetve szorosabb és távolabbi kapcsolatok megszakadása, életmódváltás) ugyanúgy viseli. A migrációval járó trauma feldolgozása a gyermek számára is pszichés teher, nemcsak a döntést meghozó szülőknek. A migránsok „kulturális sokk”ot élnek meg (Hautzinger, Hegedüs és Klenner, 2014), amelynek következményeként mind fizikai (pl. fejfájás, rossz közérzet), mind pszichés (pl. levertség, depresszió, alvás- és evészavar) tünetek jelentkezhetnek. Mindezeket a pedagógusoknak fel kell ismernie, illetve szükség esetén figyelembe kell vennie a gyermek oktatása folyamán.

g) Az iskola és a pedagógusok felkészültsége

A multikulturális nevelés fontos fogalomként jelenik meg a migráns gyerekek iskolai beilleszkedése kapcsán. Torgyik (2015) szerint a multikulturális nevelés gyüjtőfogalomként értelmezendő, amely egy paradigmaváltást jelent a korábbi pedagógiai nézőpontokhoz képest, mivel az alkalmazható széleskörü pedagógiai eszköztáron és módszereken kívül az eltérő viszonyulást, értékszemléletet is magába foglalja, így az iskola egy valódi kohéziós erővé válik a harmonikus társadalmi béke megteremtése érdekében.

Az inkluzív iskola magába foglalja a multikulturális nevelés megvalósulását. A multikulturális nevelésben a másság értékként jelenik meg, érték a gyermek fogyatékossága, eltérő szociokulturális háttere. Az inkluzív iskolai modellben a befogadandó vagy befogadott (gyermek) és a befogadó 
(iskola) egyenrangú kapcsolatban állnak egymással. Az inkluzió sikere mindkét fél alkalmazkodásra és változásra való készségén, képességén múlik.

A sikeres beilleszkedés faktora az iskola és a pedagógusok felkészültsége, befogadó szemlélete és attitüdje. A 90-es években a külföldi tanulókat fogadó legtöbb iskola pedagógiai programjában nem szerepel a külföldi gyerekek fogadásával, oktatásával, integrációjával kapcsolatos pedagógiai koncepció. Az utóbbi években a témában végzett kutatások (Jakab 2011; Torgyik 2015) megerősítik, hogy az iskolák és a pedagógusok eltérő felkészültséget mutatnak a migráns gyerekek befogadásával kapcsolatban, az interkulturális, vagy multikulturális szemlélet kevéssé jellemzi a magyar iskolákat. Az iskola felkészületlen, eszköztelen a más kultúrából érkező gyerekek oktatására, az interkulturális, illetve multikulturális nevelés eszköz- és módszertanával nincsenek tisztában (Torgyik 2015). Jakab (2011) szerint is a közoktatás színterein a migráns gyerekek befogadására irányuló pedagógia, az oktatásinevelési tevékenységek még mindig nagyon esetlegesek, következetlenek, miközben jól prognosztizálható, hogy egyre inkább szükség volna ezzel a területtel szisztematikusan foglalkozni. Jakab (2011) az iskolai kompetenciaeredményeket elemezve megállapította, hogy a bevándorlói arány, azaz a diverzitás egyértelműen pozitívan hat az eredményességre. Mind az általános iskolában, mind a 8 évfolyamos gimnáziumban megfigyelhető, hogy a nem Magyarországon született, illetve a nem magyar anyanyelvü tanulók arányának növekedése mind a matematika, mind a szövegértés eredményeit pozitívan befolyásolja. Ez hasonló eredményt mutat, mint a PISA adatok eredménye (OECD, 2016). Ugyanakkor érdemes megemlíteni, hogy a kompetenciamérések eredményének hátterében vélhetően az áll, hogy a bevándorló háttérrel rendelkezők végzettsége, illetve családiháttér-indexe meghaladja az országos átlagot.

A bevándorló vagy migráns diákok iskolai integrációjának elősegítése kétirányú kutatást és fejlesztést igényelt. Egyrészt a befogadó közeg (az oktatásirányítás, a pedagógusok, a diákok, szülők) felkészítését arra, hogy egyre nagyobb számban érkezhetnek külföldröl olyan diákok, akik speciális (nyelvi, kulturális) hátrányaik miatt többlettámogatást, többletfigyelmet igényelnek. Másrészt az integráció elengedhetetlen elem kell legyen az érkező migránsok (diákok, szülők, illetve a kialakuló intézményeik és szervezeteik) felkészítése valóságos társadalmi integrációjuk érdekében (Jakab 2011). A tanuló esélyeit megkönnyíti, ha van egy előre kialakított program, alapelv, illetve ismerjük a célcsoportokat, amelyekre tekintettel kell lenni, amire fel kell készülni. Ez a program alapvetően három fő elemből áll. Egyrészt fel kell 
készíteni a migráns gyereket és szüleit az iskolára, hiszen az iskola és a szülők közötti egészséges partnerkapcsolat ösztönzően hat a tanuló iskolai szocializációjára, előmenetelére. Másrészt fel kell készülnie az osztályfönöknek a migráns tanuló érkezésére. A pedagógusok felkészülése a szülőkkel és a gyerekkel való kapcsolatfelvétellel kezdődik, de előbb-utóbb a gyerek kultúrájával, vallásával, nemzetiségével kapcsolatos információkat is össze kell gyüjteniük, szükség esetén utána kell olvasniuk. Harmadrészt a fogadóközösségnek (pedagógusok, tanulók) fel kell készülnie a tanuló fogadására, a tanulóval és szüleivel való együttmüködésre. Nagyon fontos az eltérő nyelv, szokások, viselkedési módok, étrend elfogadtatása, értékként való bemutatása a többségi gyerekek számára.

Az Európai Unió támogatási programjai közül a TÁMOP 3.1.1 6.2.3 „A migráns tanulók oktatási problémái, a multikulturális oktatás magyarországi gyakorlatának feltárása" címủ projekt jelölte meg alapvető célként azt, hogy segítse a magyar oktatási rendszer szereplőit abban, hogy kezelni tudják azokat a kihívásokat és feladatokat, amelyek a társadalom egyre differenciáltabbá válásából következnek. A projekt keretében zajló kutatások eredményei közül két elemet látunk hangsúlyosnak. Egyrészt megállapították, hogy a pedagógusok túlnyomó többsége nincs felkészítve pedagógiai-szakmai értelemben arra, ha osztályában váratlanul megjelenik egy más nemzetiségű, kisebbségi vagy éppen fogyatékos vagy tanulási zavarral küzdő gyerek. Másrészt a kutatás ráirányította a figyelmet arra, hogy a bevándorlókról, illetve a hozzájuk tartozó közösségekről a tankönyvekben és a médiában megjelenő képek az esetek többségében leegyszerüsítettek, személytelenek és sztereotipizálóak, ezáltal negatív hatással van az érintett csoportok sikeres integrációjára, amit mindenképpen oldani kellene. Jakab (2011) alapján az oktatási rendszer valamennyi szereplöjének egyre inkább tudatosítania kell a bevándorlók társadalmi és iskolai integrációjának ellentmondásos helyzetét, és az ebből adódó nehézségeket.

A bevándorlók társadalmi és iskolai integrációjához toleranciára és empátiára van szükség, hiszen a különböző kultúráknak kölcsönösen alkalmazkodniuk kell egymáshoz. El kell fogadnunk és meg kell tanulnunk, hogy multikulturális társadalomban élünk, annak előnyeivel és hátrányaival (Jakab, 2011).

\section{h) Szociális segitők, mentorok támogató jelenléte}

Az iskola pedagógiai, módszertani felkészületlensége a multikulturális oktatásra nagyban nehezíti a migráns tanulók beilleszkedését és iskolai 
előmenetelét. Ugyanakkor az iskola befogadó attitüdje, a modern pedagógia módszerek alkalmazása (pl. mentor, tutor, tanulópár, szülöközösség, iskolaelőkészítő, migráns hátterű pedagógusok alkalmazása, a nyitott iskolai modell terjesztése), a támogató pedagógiai asszisztencia elősegíti a család és az iskolakapcsolatának stabilizálódását, ezáltal a tanulói teljesítmény javulását. (Jakab 2011). Zatykó, Schumann és Balogi (2013) az iskolai integrációt segítő tényezőként nevezte meg a szociális segítőket, illetve a mentorokat, amelyek a közvetítő szerepét betöltve, hidalják át az iskola és a család közötti kommunikációs gátakat, illetve közremüködnek a család menekültstátuszával kapcsolatos közigazgatási ügyek kezelésében. Az iskolákban végzett szociális segítő tevékenység kapcsán 2018. szeptemberében olyan módon változott meg a jogszabályi környezet, amely alapjaiban befolyásolhatná a migráns a gyerekek befogadásának folyamatát. Az EMMI 15/1998. (IV. 30.) Nm rendeletének módosítása kötelezően ellátandó feladatként határozza meg az iskolai szociális segítést, és egyúttal normatív finanszírozást is rendel hozzá. Ennek az új típusú szolgáltatásnak a szakmai alapjait és képzési hátterét az iskolai szociális munka jeleníti meg, amely az elmúlt években a felsőoktatásban akkreditált egy éves szakirányú továbbképzési szakként létezett a képzési palettán. A képzés az iskolában felelhető számtalan társadalmi probléma kezelésének módszerét tartalmazza, de eredeti akkreditációs anyagában még nem szerepel a migrációs problémák kezelésének módszertana. Az egyes képző intézmények szakmai közösségének tájékozottsága, érzékenysége és felkészültsége eredményezheti a migrációs problémák bemutatását és kezelési lehetőségeinek oktatását. A Szociális és Gyermekvédelmi Főigazgatóság az Európai Uniós támogatással 2019-ben egy pilot projekt keretében hirdetett meg 105 órás óvodai és iskolai szociális segítő képzést, de annak belső tartalma sem tér ki a migrációs problémák kezelésére.

\section{Összefoglalás}

A fentiek alapján megállapítható, hogy a migráns gyerekek befogadásával kapcsolatos feladatok napjainkban (is) jelenős kihívások elé állítják a pedagógusokat. Az alapvető értékek, mint az empátia, tolerancia, nyitottság, elötérbe kerülnek a szocializációs, illetve beillesztési folyamatban. A migránsok beillesztéshez a felkészítés mellett egyik jó módja lehet a fogyatékos személyeknél már jól bevett gyakorlat, az „érzékenyítő tréning” (Dajnoki 2014; Hrabéczy 2016; Dajnoki, Kőmíves és Héder, 2017). Bár ez a kifejezés migráns gyerekek kapcsán inkább nemzetközi irodalmakban jelenik 
meg programként, az előzetes felkészülés-felkészítés, a másik fél sajátosságainak megismerése mindenképpen elönyös az integrációs folyamatban. A kutatási eredmények alátámasztják, hogy a diverzitás, a sokszínűség elősegíti a szinergiát és pozitívan hat az eredményességre. A „különbség érték”, nem csak a munkahelyen, hanem az iskolában is.

A kutatási eredmények alapján megállapítható, hogy az iskola a társadalmi problémák megoldásában kevésbé hatékony, ugyanakkor az iskola müködéséhez igazított problémakezelés a pedagógiai gyakorlat átrendezéséhez, hosszabb távon pedig a társadalmi eredményességhez is hozzájárulhat. A pedagógiai folyamat kiegészítéseként tekintünk az iskolai szociális munka új típusú szolgáltatás rendszerére. Az iskolai szociális munkások képzésének tartalmi elemeit megítélésünk szerint érdemes lenne kiterjeszteni a migráns gyerekek befogadását segítő módszerek ismertetésére, annak széles körü alkalmazására.

\section{Felhasznált irodalom:}

1. Barna M. - Nguyen Luu, L. A. - Várhalmi Z. (2012): Az én házam egy keleti ház a nyugati világban - Nemi szerepek és beilleszkedés a konfuciánus és muszlim hagyományú országokból származó bevándorlók körében. Budapest, ICCR Budapest Alapítvány, 36.

2. Bronfenbrenner, U. (1979): The Ecology of Human Development: Experiments by Nature and Design. Harvard University Press, Cambridge MA.

3. Dajnoki K. (2014): Fogyatékos munkavállalók beillesztésének sajátosságai, különös tekintettel az érzékenyítő tréningekre. Taylor: Gazdálkodás- és Szervezéstudományi Folyóirat: A Virtuális Intézet Közép-Európa Kutatására Közleményei (2064-4361): VI. évf. 1-2. sz. No. 14-15., 157-167.

4. Dajnoki K. - Kömíves P. M. - Héder M. (2017): Integration Opportunities of Migrants, with Especial regards to Sensitization Programs. CrossCultural Management Journal XVIX:(Issue 11) 67-74.

5. Engler Á. (2017): A család, mint erőforrás és a szakmai pályafutás. Budapest, Gondolat Kiadó, 17-33.

6. Európai Bizottság (2011): A Bizottság közleménye a Tanácsnak, az Európai Parlamentnek, az Európai Gazdasági és Szociális Bizottságnak és a Régiók Bizottságának: A harmadik országbeli állampolgárok integrációjának európai programja. Brüsszel, 455. 
7. Feischmidt M. - Nyíri P. (2006): Nem kívánt gyerekek? Migránsok a magyar közoktatásban. MTA Nemzeti-etnikai Kisebbségkutató Intézet Nemzetközi Migrációs és menekültügyi Kutatóközpont, Budapest, 261.

8. Fejes J. B. (2013): Miért van szükség deszegregációra? In Fejes J. B. \& Szűcs N. (szerk.): A szegedi és a hódmezővásárhelyi deszegregációt támogató hallgatói mentorprogram. Öt év tapasztalatai. Belvedere Meridionale, Szeged, 15-35.

9. Fónai M. - Pénzes M. (2009): A migráció integrált társadalmi megközelítései. Nyíregyháza, Észak-magyarországi Szenvedélybetegségeket Megelöző Egyesület - Human Net Alapítvány, 210.

10. Gödri I. - Tóth P. P. (2005): Bevándorlás és beilleszkedés - A szomszédos országokból Magyarországra irányuló bevándorlás az ezredfordulón. Kutatási Jelentések. Budapest, KSH Népességtudományi Kutatóintézet

11. Gödri I. (2008): Bevándorlók munkaerő-piaci integrációját meghatározó tényezők Magyarországon - a kapcsolati erőforrások szerepe. Statisztikai Szemle 86. évf. 6. sz.. 533-563.

12. Gödri I. (2017): Az integráció mutatói és esélykülönbségei a Magyarországon élő bevándorlók körében. Demográfia. 60. évf. 1. sz. 5-55.

13. Hautzinger Z. - Hegedűs J. - Klenner Z. (2014): A migráció elmélete. Nemzeti Közszolgálati Egyetem Rendészettudományi Kar. Budapest. ISBN 978-615-5305-54-2

14. Heckmann, F. (2001): Integration Research in European Perspective. In Demographic and Cultural Specifity and Integration of Migrants. Materialienzur Bevvrialienzur Bevevnzur. Heft 103. Wiesbaden, Bundesinst. für Bevölkerungsforschung, 59-75.

15. Hrabéczy A. (2016): Érzékenyítő tréning a sajátos nevelési igényü gyermekek, ezen belül a látássérült gyermekek integrációja, inklúziója érdekében, iskoláskorú gyermekek számára. In: Koncz István; Mező Ferenc; Szova Ilona - Perspektivikus kaleidoszkóp II., Budapest, Magyarország: Professzorok az Európai Magyarországért Egyesület, 114-118.

16. Illés K. - Medgyesi A. - Kováts A. - Vámos Á. (2009): A migráns gyerekek oktatása. Budapest, Menedék - Migránsokat Segítő Egyesület, 49. ISBN 978-963-87923-4-1 
17. Jakab Gy. (2011): A migráns tanulók oktatási problémái, a multikulturális oktatás magyarországi gyakorlatának feltárása, Új Pedagógiai Szemle, 144-164. Letöltés helye:

http://folyoiratok.ofi.hu/sites/default/files/article_attachments/upsz_2011_ 8-9_06.pdf

18. Juhász J. - Makara P. - Makara E. (2011): A munkaerő piaci integráció kihívásai Magyarországon - A harmadik országbeli bevándorlók beilleszkedésének esélyei és korlátai. Kutatási Zárótanulmány, Budapest, Panta Rhei Bt.

19. Kincses Á. (2015): A nemzetközi migráció Magyarországon és a Kárpátmedence magyar migrációs hálózatai a 21. század elején. Budapest, Központi Statisztikai Hivatal. ISBN 978-963-235-484-2

20. Kováts A. (2013): Bevándorlók integrációja Magyarországon korábbi kutatások adatai alapján. In: Kováts András (szerk.): Bevándorlás és integráció magyarországi adatok, európai indikátorok. Budapest, MTA Társadalomtudományi Kutatóközpont, Kisebbségkutató Intézet. ISBN 9789637372889

21. Köznevelési Statisztikai Évkönyv 2018/19. Letöltés helye: https://20152019.kormany.hu/download/7/6e/d1000/Köznevelési\%20statisztikai\%20évk önyv_2018-2019.pdf\#!'DocumentBrowse, 27-39, Letöltés ideje: 2020. 10. 16.

22. KSH (2018): Mikrocenzus 2016. 10. Nemzetközi vándorlás. Központi Statisztikai Hivatal. Budapest. Letöltés helye:

https://www.ksh.hu/docs/hun/xftp/idoszaki/mikrocenzus2016 /mikrocenzus_2016_10.pdf, Letöltés ideje: 2020. 09. 29.

23. Meleg Cs. (2015): Nevelésszociológiai problémakörök és nézőpontok. In: Varga Aranka (szerk.) A nevelésszociológia alapjai. Pécs, Pécsi Tudományegyetem Bölcsészettudományi Kar Neveléstudományi Intézet, Wlislocki Henrik Szakkollégium. 19-49.

24. Melegh A. - Kovács É. - Gödri I. (2010): „Azt hittem, célt tévesztettem” - A bevándorló nők élettörténeti perspektívái, integrációja és a bevándorlókkal kapcsolatos attitüdök nyolc európai országban. KSH NKI Kutatási Jelentések 88. Budapest, KSH Népességtudományi Kutatóintézet

25. OECD (2016): PISA 2015 Results, Volume I, Excellence and Equity in Education. Paris, PISA OECD Publishing. Letöltés helye: http://dx.doi.org/10.1787/9789264266490-en, Letöltés ideje: 2020. 10. 10. 
26. Németh Sz. (2009): Sajátos nevelési igényű migráns tanulók. Oktatáskutató és Fejlesztő Intézet. Budapest. Letöltés helye: https://ofi.oh.gov.hu/tudastar/egyuttneveles-szakmai/nemeth-szilviasajatos, Letöltés ideje: 2020. 10. 08.

27. Örkény A. - Székelyi M. (2010): Az idegen Magyarország. A bevándorlók társadalmi integrációja. Budapest, ELTE Ötvös Kiadó. ISBN 9789633120262

28. Papp Z. A. (2017): Külföldi tanulók jelenléte és eredményessége a magyar közoktatásban. Educatio 26 (3), 335-351.

29. Pásztor A. (2006) Őshonos kisebbség mint nem önkéntes kisebbség. Ogbu kulturális-ökológiai elméletének tesztelése Európában. Szociológiai Szemle, Vol. 16. No. 2. 3-36.

30. Pusztai G. (2009): A társadalmi tőke és az iskola. Kapcsolati erőforrások hatása az iskolai pályafutásra. Budapest: Új Mandátum Könyvkiadó. 29-45.

31. R. Fedor A. (2015): Egyensúlyban? - A munkaerö-piaci karriertől a familiarizmusig Debrecen, Debreceni Egyetemi Kiadó, 252.

32. R. Fedor A. - Pálosi R. (2018): A fiatalok pályaorientációs döntései az iskola és a családi háttér tükrében. Tudásmenedzsment 19: 1, 52-61.

33. Torgyik J. (2015): Multikulturalizmus, interkulturális nevelés. In: Varga Aranka (szerk.) A nevelésszociológia alapjai. Pécs, Pécsi Tudományegyetem Bölcsészettudományi Kar Neveléstudományi Intézet, Wlislocki Henrik Szakkollégium, 161-183.

34. Zatykó J. - Schumann R. - Balogi A. (2013): Harmadik országbeli tanulók iskolai beilleszkedése Budapesten és Szegeden. Kutatási zárójelentés, Szeged, Dél-Alföldi Regionális Társadalomtudományi Kutatási Egyesület, 124. 